\title{
Some Most Important Medicinal Plants used by Pulaya Tribes from Thirumoorthy Hills of Tirupur District, Tamilnadu, India
}

\author{
Gopi Krishnan $\mathbf{R}^{\mathbf{1}}$, Patharaj $\mathbf{J}^{\mathbf{2}^{*}}$ \\ ${ }^{1}$ School of life science Department of Botany, Periyar University, Selam, India \\ ${ }^{* 2}$ Vikas Educational institution Tirupur, Tamilnadu, India
}

*Corresponding Author: Patharaj, Vikas Educational institution Tirupur, Tamilnadu, India.

\begin{abstract}
An ethnomedical survey was carried out among the Pulaya ethnic groups of Tirumurthy Hills, Western Ghats, Tirupur region of Tamil Nadu, India. This study includes 50 most valuable medicinal plants that have more curative properties were studied in detail. Pulaya Ethnic use herbal medicine to treat dysentery, diabetes, jaundice, asthma, fertility, anti fertility, hay fever etc.
\end{abstract}

Keywords: Ethnobotany, Pulaya tribes, Thirumoorthy hills, Ailments etc.

\section{INTRODUCTION}

Native herbal remedies are usually used against many infectious diseases from long back. Plant and plant products are recognized to possess excellent antimicrobial properties and play an important role in preventing and curing both contagious and non contagious diseases. The existing accepted allopathic practice has gradually developed over the years of scientific efforts of scientists; however, the bases of development remain in the roots of traditional medicine. Plants are the most exclusive source of drugs for the majority of the human population. The use of plants in traditional medicine system has been extensively documented in many different cultures and countries of the world.

Conventional medicine has remained as the most reasonable and easily reachable source of treatment in the primary health care system of resource-poor communities. The local people have a long record of traditional plant practice for therapeutic purposes. The curative use of plants is very old. The writings designate that remedial use of plants is as old as 4000 - 5000 BC. In India, initial references of use of plants as medicine appear in Rig Veda that is believed to be written between $1600-3500$ BC. later on the properties and therapeutic uses of medicinal plants were studied in detail and noted empirically by the ancient physicians (an indigenous system of medicine) which are a basic foundation of ancient medical science in India (Prakash and Gupta 2005). The medicinal plant is a vital element of indigenous medical systems all over the world. The ethnobotany provides a wealthy resource for natural drug research and development (Farnsworth, 1990). The conventional use of herbal medicines implies considerable historical use, and this is positively true for many products that are available as customary herbal medicines. Some developing countries, a huge amount of the population relies on traditional practitioners and their armamentarium of medicinal plants in order to meet healthcare requirements. Though modern medicine may exist side-by-side with such traditional practice, herbal medicines have often maintained their popularity for historical and cultural reasons. (Vishwakarma et al.,2013). Natural products have played a vital role right through the world in treating and preventing human ailments. Natural product medicines have come from various source resources including terrestrial plants, terrestrial microorganisms, marine organisms, and terrestrial vertebrates and invertebrates (Newman et al., 2000) and its importance in current medicine has been discussed in different reviews and reports (Jones et al., 2006).

\section{Materials And Methods}

Medicinal plants were collected according to the method adopted by Schltes (1960); Jain (1981) and Martin (1995). Extensive field trips were conducted to remote rural settlements. From each hamlet, three or more than three local herbal healers were interviewed in order to obtain information about plant products which used to cure various infectious diseases. Here both men and women medicinal healers were asked to explore their view on the utilization of medicinal plants. However, the men 
medicinal healers have given more priority because they seemed to have more knowledge about the utility plants in curing various diseases. They know more about remedies for children, disease, and ailments associated with heart and body pain. Men new more about the treatment of bone fracture, cuts, wounds, scorpion and snake bites. The traditional healers (informants) were taken to the field and record of medicinal plants is made. The informants were requested to explain the medicinal properties, vernacular name, preparation method, and mode of administration. All the above said information was recorded on time.

\section{RESULT}

\subsection{Taxonomic Diversity}

In the present study, 55 medicinal plants belonging to 49 genera of 31 families used by Pulaya communities were collected and studied after carrying out a simple interview. The plants were collected from various conservancies around the study area and witnessed with photographs. Different parts were harvested depending on the parts the community used in the treatment of the range of diseases. According to the investigation among the plant parts, the leaves and fruits are mostly used than other parts of the plants. Most of the phytomedicine from this region was used to treat cough, cold, dysentery, fever and other viral, bacterial and protozoan diseases.

The families of Solanaceae and Euphorbiaceae comprises highest number of species contain 7 (12\%) and 5 (9\%) species respectively.

\subsection{Interview with Traditional Healers (Informant Selection)}

There were 50 elder's from Pulaya tribes were involved. From each hamlet 10 informants ( 5 men and 5 women) were selected, the age of informants ranged from 25- 80 with an average 52 years for men and 51 years for women. Most of the selected informant belonging to those who have strong knowledge about the use of folk medicine. About $25(50 \%)$ informants utilized medicinal plants and prepared only when required for them.16 (32\%) informants not only utilized for themselves when required but also prepared for other people. Nearly $4(8 \%)$ persons are regular practitioners and treated as professional as they treat patients in full time and the remaining $5(10 \%)$ informants said that they do not utilize plant species.

\subsection{Morphological Parts used, Habit, Distribution and Ailment Category}

\section{A. Morphological Parts used}

Different plant parts such as leaf, root, barks, rhizome, flowers, shoot, fruit, and whole plant are used to treat different ailments. Leaves are used in the majority of cases with 34 species followed by fruit and seed with 15 species, the use of whole plant 7 species, bark and flower with 5 species each, the use of root is 4 species and others 2 species (Table $1 \&$ fig 1 )

Table1. Morphological Parts Used for Ailments

\begin{tabular}{|c|c|c|c|}
\hline S.N & Plant Parts used & Number of species & Expression in Percentages \\
\hline 1 & Whole plants & 7 & 12.7 \\
\hline 2 & Bulb, tuber, and rhizome & 2 & 3.6 \\
\hline 3 & Root & 4 & 7.2 \\
\hline 5 & Leaf & 34 & 61 \\
\hline 6 & Fruit and seed & 15 & 27 \\
\hline 7 & Bark & 5 & 9 \\
\hline 8 & Flower & 5 & 9 \\
\hline
\end{tabular}

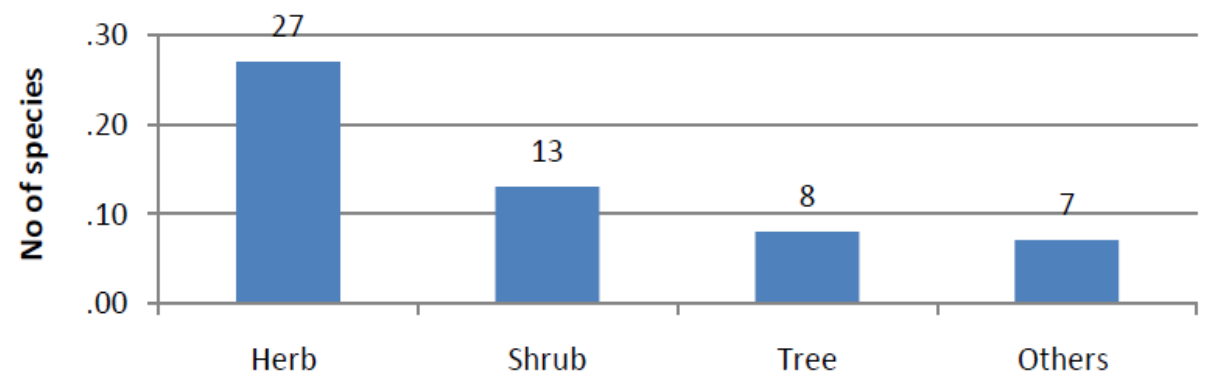

Figure1. Distribution under different forms of habit 


\section{B. Medicinal Plant Distribution in Terms of Habit}

In terms of plant habits, herbs with $27(49 . \%)$ species constitute the largest number of species followed by shrubs with $13(23.6 \%)$ species, trees and other used $8(14.5 \%)$ and $7(12.7 \%)$ respectively (Table $2 \&$ fig 2 )

Table2. Distribution under different forms of habit

\begin{tabular}{|c|c|c|c|}
\hline S.N & Habit & Number of Species & Percentage \\
\hline 1. & Herbs & 27 & 49 \\
\hline 2 & Shrubs & 13 & 23.8 \\
\hline 3 & Tree & 8 & 14.5 \\
\hline 4 & Other & 7 & 12.7 \\
\hline 5 & Total & 55 & 100 \\
\hline
\end{tabular}

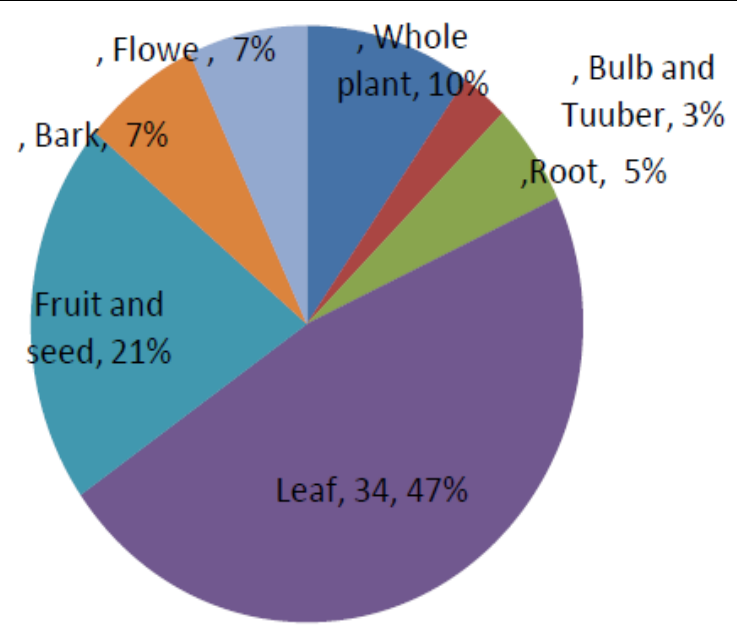

Figure2. Plant parts used for the various ailments

\subsection{Documentation of Ethnomedicinal Medicinal Plants}

\section{Acacia dealbata Link.}

Family

: Mimosaceae

Common Name

: Eng-Beng ; Hindi-Ritha ; Tamil- Syakai .

Parts used

: Fruit and leaves

Used by Pulaya

: Fruit paste applied to all over the body to cure

skin disease and itching. Leaf paste applied to head and body for cooling effect.

\section{Acalypha indica $L$}

Family

: Euphorbiaceae

Common Name

: Eng-Birch-leaved acalypha ; Tamil- kuppai meni

Parts used : Leaves

Used by Pulaya

: Leaf past applied for the skin burn, scabs

\section{Achilla millefolium $L$}

Family

Common Name

\section{: Asteraceae}

Morphological parts used

: Eng-Yarrow Milfolia; Tamil- Syakai

Used by Pulaya

: Leaves and flowers

: The herbal infusion is used for diarrhea, menstrual disorder, cold and fever. Leave past applied to treat skin rashes and eczema. 


\section{Adathoda vasica Ness}

Family

: Acanthaceae

Common Name

: Eng-Malbar nut ; Tamil- Arusha ; Hindi-Adusogi

Parts used

: Leaves, bark and root

Used by Pulaya

: Dried leaf powder or leaf decoction used an herbal treatment for Asthma, cough, cold and other respiratory disorder. Juice made from leaves used in the treatment of diarrhea, dysentery and cough .

\section{Chlorophytum cosmosum Thunb. Jacques}

Family

Common Name

Parts used

Used by Pulaya
: Lilliaceae

: Eng- spider plant; Hindi-Musli

: Root

: Root paste along with honey or green leaf tea taken to reduce cholesterol (LDL). This infusion also used to treat diabetes. Leaf paste along with tea or honey taken to reduce body heat.

\section{Aloe vera $L$}

Family

: Lilliaceae

Common Name

: Eng- Indian aloe; Tam- Sothu kathalai; Hindi - Gheeku

Parts used

: Leaves

Used by Pulaya

: Leaf and root extract is used for digestion, skin disease, mucilage is used for inflammation.

\section{Alternanthera pungens Kunth}

Family

Common Name

Parts used

Used by Pulaya
: Amaranthaceae

: Eng- Khaki weed; Tamil- Ottara mul

: Leaves

: The leaves are made into paste and applied over the boils for early ripening and bursting.

\section{Andrographis paniculata Ness}

Family

: Acanthaceae

Common Name

: Eng-Great king of bitters: Tamil- Nelavembu ; Hindi- Piyaz

Parts used

: Leaves and bulbs

Used by Pulaya

: The whole plant is made into paste and applied all over the body and given. orally as an antidote for snakebite. Green leaves used for reliving constipation.

\section{Argemone mexicana $L$}

Family

: Papavaraceae

Common Name

: Eng- prickly poppy; Hind- Sathya; Tamil Bharmathand

Parts used

: Whole plant

Used by Pulaya

skin disease, scorpion bite scabies and skin leshmania 


\section{Bambusa bambos L. Voss}

$\begin{array}{ll}\text { Family } & : \text { Poaceae. } \\ \text { Common Name } & \text { : Eng- Bamboo; Tamil- Moongil } \\ \text { Parts used } & : \text { Leaves bark and seed. } \\ \text { Used by Pulaya } & : \text { Young stem and tender shoot used for bone setting and bone fracture. }\end{array}$

\section{Berberis tinctoria Lesch}
Family : Berberdiaceae.
Common Name : : Eng- Nilgiri berberry,
Parts used : Leaves and fruit.
Uses by Pulaya $\quad:$ It is used in the disorder of jaundice, ulcer, urinal infection, and stomachache

\section{Casia auriculata $L$}

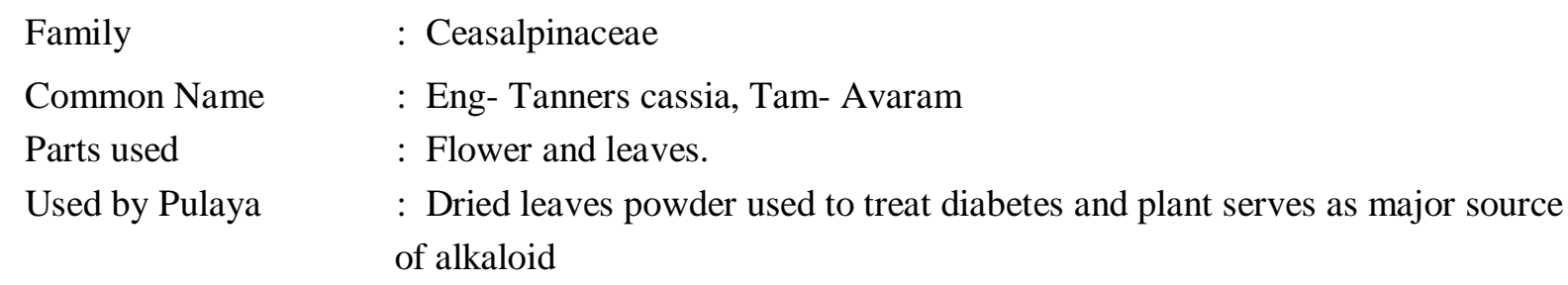

\section{Casia occidentalis Link}

$\begin{array}{ll}\text { Family } & \text { : Ceasalpinaceae } \\ \text { Common Name } & \text { : Eng- Foetid cassia, Tam- Nattam thakarai } \\ \text { Parts used } & \text { : Root and leaves. } \\ \text { Used by Pulaya } & \text { : Leaf paste applied externally all over the body to relieve any kind of } \\ & \text { inflammation. }\end{array}$

\section{Chenopodium ambrosioides L. Mosyakin}

Family

: Chenopodiaceae

Common Name

: Eng- Mexican tea, Hindi-Khatua, Tam- Katta sambadam

Parts used

: Leaves.

Used by Pulaya

: Crushed leaf paste mixed and taken for stomachache.

\section{Cinchona officinalis Linn}

Family

: Rubiaceae

Common Name $\quad$ : Eng- yellow cinchona, Hindi-cinchona, Tam- chincona

Parts used

: Leaf and bark

Used by Pulaya

: Cinchona tonic prepared from cinchona bark used to treat fever, stomachache, vomiting and headache

\section{Cissus quadrangularis $L$}

Family

Common Name

Parts used

Used by Pulaya
: Vitaceae

: Eng - Hadjor, Hindi - Hadjora, Tam- Pirandai

: Whole plant

: The root paste is applied for the cuts and wounds for rapid healing. Leaf infusion used to reduce fever and pain 


\section{Cochleria armoracia/ Armoracia rusticana Gaertn. B. Mey \& Scherb}

Family

: Brassicaceae

Common Name

: Eng- Hourse radish

Parts used

: Leaf and root

Used by Pulaya

: Boiled leaf taken internally to cure cough and ulcer. Root decoction used for treatment of asthma.

18. Coronopus didynamous. $L$

$\begin{array}{ll}\text { Family } & \text { : Brassicaceae } \\ \text { Common Name } & \text { : Eng- Lesser swine's } \\ \text { Morphological parts used : } & \text { Whole plant }\end{array}$

Used by Pulaya $\quad$ : Young plant is crushed and applied on the fore head to relieve headache. Paste used for cuts and wounds.

\section{Crotolaria verrusoca Linn}

$\begin{array}{ll}\text { Family } & \text { : Fabaceae } \\ \text { Common Name } & \text { : Eng-Hemp; Hindi-Bansana; Tam-Perya Salangai chedi } \\ \text { Parts used } & \text { : Leaf, flower } \\ \text { Used by Pulaya } & \text { : Leaf infusion along with milk given to patient to treat Diarrhea and eye } \\ & \text { infection. }\end{array}$

\section{Cymbopogan confetiflorus $L$}

Family

: Poaceae

Common Name

Parts used

: Eng- Lemon grass ,

Used by Pulaya

$$
\text { : Leaf and shoot }
$$

: Leaf past is made to tea to remedy digestive problem diarrhea and stomachache. It relaxes the muscles of stomach and gut.

\section{Cytisus scoparius $L$}

Family

Common Name

Parts used

Used by Pulaya

: Fabaceae

: Eng- Scotch broom. ,

: Flower and seed

: It is a diuretic and stimulates urine formation. The young herbaceous tips of flowering shoots are cardio tonic, cathartic, and emetic.

\section{Dodonea viscose $\mathbf{L}$}

Family

: Sapinndaceae

Common Name

: Eng- Hop bush; Hindi- Aliar; Tam- Velari

Parts used

: Leaves.

Used by Pulaya

: Leaves slightly warmed over the fire and placed on forehead to relieve headache. In addition, it is used for joint pain and bone fracture.

\section{Drymaria cordata $L$}

Family

Common Name

Parts used

Used by Pulaya
: Caryophyllaceae

: Eng- Chick weed

: Leaves.

: infusion of the leaves or whole plant is used as a treatment for jaundice, colds, biliousness, and malaria 


\section{Elaeocarpus serratus $L$}

Family

: Elaeocarpaceae

Common Name

: Eng- Wild olive/ Nilgiri olive

Parts used

: Leaves and fruit.

Used by Pulaya

: Leaf infusion is used in the treatment of rheumatism and are an antidote to poison. Fruits are used in dysentery and diarrhea.

\section{Eleaganus kologa L}

Family

: Eleagnaceae

Common Name

: Eng- Oleaster

Parts used

: Flowers and fruits.

Used by Pulaya

: The flowers are astringent and cardiac. The fruit is astringent and rich in. vitamins, minerals and contain antioxidant properties

\section{Emblica officinalis $L$}
Family
:Euphorbiaceae
Common Name
: Eng- Goose berry; Hindi- amla; Tam- Nellika
Parts used
: Bark, leaves and fruits.
Used by Pulaya
: Taking one or two fruit daily improves vision, regulate blood pressure, reduces the respiratory disorder and promotes digestion and urine formation

\section{Ficus racemosa Linn}

Family

: Moraceae

Common Name

: Eng- Cluster fig, Hindi- Gular; Tam- Athi.

Parts used

: Latex, leaves and fruits.

Used by Pulaya

: The dried un ripened fruit made in to fine powder and mixed with either milk or honey. This mixture used to treat haematuria and menorrhagia.

\section{Ficus exasperata Linn}

Family

: Moraceae

Common Name

: Eng- Sand paper tree, Hindi- Pipal; Tam- Athi.

Parts used

: Leaves and fruits.

Used by Pulaya.

: Un ripened fruit is well ground and made in to powder for making soup.

Soup given once in a week for purification of blood.

\section{Fluggea leucorpyros Willd}

$\begin{array}{ll}\text { Family } & \text { : Euphorbiaceae } \\ \text { Common Name } & \text { : Eng- Bush weed; Hindi- Shinar; Tam- Mullu pulatti } \\ \text { Parts used } & \text { : Fowers and fruits. } \\ \text { Used by Pulaya } & \text { : latex of this plant species applied on open woond, scar and cuts for rapid } \\ & \text { recovery. }\end{array}$

30. Fragaria vesca $\mathbf{L}$

$\begin{array}{ll}\text { Family } & \text { : Roaceae } \\ \text { Common Name } & \text { : Eng- Wild strawberry } \\ \text { Parts used } & : \text { leaves and fruits. }\end{array}$

Used by Pulaya: An infusion of the leaves and tea or honey mixture cures anemia and nervousness. Fruit contain high antioxidants 


\section{Ipomeia nil $\mathbf{L}$}

Family : Convolvulaceae

Common Name

: Morning glowry; Tam- siruthalai

Parts used

: Leaves

Used by Pulaya

: It is used in the treatment of fever, oedema, oliguria, ascasriasis and constipation. Seed contain small amount of hallucinogen, which cures various. mental disorder

\section{Jatropa curcus $L$}

Family

: Euphorbiaceae

Common Name

: Eng- Purging nut; Tam- Kattamanakku

Parts used

: Tender stick and latex.

Used by Pulaya

: The tender stick used as toothbrush for dental and bleeding gum problem.

Daily once in the morning for three days.

\section{Jatropa gosipifolia Lag}

Family

Common Name

Parts used

Used by Pulaya
: Euphorbiaceae

: Eng- Belly ache bush; Tam- Eli amanakku

: Leaves and tender shoot

: Both Thoriya and Baduga community use this plant leaves for the treatment of leprosy. And its sap used as antidote for the snake bite.

\section{Leucas aspera Wild}

Family

: Lamiaceae

Common Name

Parts used

: Eng- leucas or Gumo; Tam- Thumbai

Used by Pulaya
: Leaves

: Leaf infusion used to treat skin allergy, toothache and small pox.

\section{Leucas lavandulifolia Sm}
Family
: Lamiaceae
Common Name
: Eng- Gumo ; Tam- Thumbai
Parts used
: Leaves .
Used by Pulaya
: Leaves are mixed with jiggery and made in to Past and given orally to the children suffering from Cold and Cough.

\section{Laurus nobilis $L$}

Family

: Lauraceae

Common Name

: Eng- Sweet bay

Parts used

: Leaves and fruits.

Used by Pulaya

: Leaf infusions are reputed to soothe the stomach and relieve pain and flatulence.

\section{Mahonia leschenaultia Wall. ex Wt}

Family

Common Name

Parts used

Uses: by Badagas
: Berberdiae

: Eng- Mahonia/ Takida

: Leaves stem

: Infusion of leaves commonly used against swelling, fever, inflammation, jaundice, and dysentery. 


\section{Melaleuca alternifolia Maiden. Betche}

Family

: Myrtaceae.

Common Name

: Eng- Narrow leaved paper bark/ narrow leaved tea tree.

Parts used

: Leaves, young shoot

Used by Pulaya

: Leaf infusion used externally to treat stings, burns, wounds, skin infection, warts and veginal infection.

\section{Mentha aravensis $L$}

Family

: Laminaceae.

Common Name

: Eng- Japanese mint.

Parts used

: Leaves,

Used by Pulaya

: Oil obtained from tea tree is strongly antiseptic and diaphoretics. Leaf infusion used for the mouth fresh and cough.

\section{Nicanra physaloides. $L$}

Family

: Solanaceae.

Common Name : : Eng-Shoofly / Apple of Peru; Tam- Sudaku thakkalli

Parts used : Leaves

Used by Pulaya

: Leaf paste applied to the skin to cure cuts and wounds.

\section{Osimum basilicum $L$}

Family

Common Name

Parts used

Used by Pulaya
: Lamaceae.

: Eng-Shruby Basil; Tam- KarunThulasi .

: Leaves,

: Leaf juice given orally ( one tea spoon ) to children to cure cold and bronchitis. Leaf infusion also used for blood purification.

\section{Passiflora caerulea $L$}

Family

Common Name

Parts used

Used by Pulaya
: Passifloraceae.

: Eng- Blue Passian fruit ; Hindi- Jhumka lata..

: Leaves, fruit

: Leaf infusion used in the treatment of insomnia and headache.

\section{Phyllanthus amarus Schum. Thonn}

Family

: Euphorbiaceae

Common Name

: Tam- keezanalli :.

Parts used

: Whole plant,

Used by Pulaya

: Handful of leaves is made into a paste and mixed with goat milk. It is given orally to treat jaundice.

\section{Plumeria alba $L$}

Family

Common Name

Parts used

Used by Pulaya
: Apocynaceae

: Eng- White champa ; Tam-Perumal arali

: Stem Bark

: The stem bark is made in to paste with dry chilli and applied on the forehead to cure migraine. 


\section{Rubia cordifolia Linn}

$\begin{array}{ll}\text { Family } & \text { : Rubiaceae } \\ \text { Common Name } & \text { : Eng- Indian madar Castor ;Tam- Savalikodi } \\ \text { Parts used } & \text { : Whole plant. } \\ \text { Used by Pulaya } & \text { : The whole plant made into paste and applied to skin to cure skin diseases. } \\ & \text { Daily once for five days or until cure. Leaf paste kept on eyelid to cure eye } \\ & \text { infection. }\end{array}$

\section{Siegesbeckia orientalis $L$}

Family : Asteraceae

Common Name $\quad$ : Eng- Siegesbekia; Tam- Kadambu

Parts used : Leaves

Used by Pulaya $\quad$ : Leaves paste applied all over the body to cure skin disease.

\section{Solanum anguvi $L$}

Family

: Solanaceae

Common Name

: Eng- Night shade; Tam- Kattu sundai

Parts used

: Fruit and leaves

Used by Pulaya

: The Fruits are used fresh or dried and ground in to powder and mixed with milk. Milk given orally to reduce Blood pressure and dysentery.

\section{Solanum elaeagnifolium $L$}

Family

: Solanaceae

Common Name

: Eng- Silver leaf Nightshade; Tam-

Parts used

: Fruit and leaves

Used by Pulaya

: The Fruits and leaves well ground and made into paste and taken orally to cure tooth aches, sore throats and also used for snake bite.

\section{Solanum sisymbrifolium $L$}

Family

: Solanaceae

Common Name

: Eng- Night shade; Tam- Aamanakku /Kotta muthu

Parts used

: Fruit and seed

Used by Pulaya

: The Fruits are used fresh or dried and ground in to powder and mixed with milk. Milk given orally to reduce Blood pressure.

\section{Solanum torvum $L$}

$\begin{array}{ll}\text { Family } & \text { : Solanaceae } \\ \text { Common Name } & \text { : Eng- prickly nightshade/ Turkey berry; Tam- Sundakaa } \\ \text { Parts used } & \text { : Fruit } \\ \text { Used by Pulaya } & : \text { The immature green fruits are made in to a paste and given orally to children } \\ & \text { as a febrifuge. Daily once in the morning for five days. }\end{array}$

\section{Solanum trilobitum $L$}

\section{Family}

Common Name

Parts used

Used by Pulaya

\section{: Solanaceae}

: Eng- prickly night shade/ Turkey berry ;Tam-Tudhuvali

: Fruit

: The immature green fruits are made in to a paste and given orally to children as a febrifuge, dysentery, cough. 


\section{Solanum viarum $L$}

$\begin{array}{ll}\text { Family } & : \text { Solanaceae } \\ \text { Common Name } & : \text { Eng- tropical soda apple } \\ \text { Parts used } & : \text { Leaves. } \\ \text { Used by Pulaya } & : \text { The leaf and fruit decoction used for the treatment of rheumatic arthritis, } \\ & \text { asthma, leukemia and obesity. }\end{array}$

\section{Taraxacum officinale Webbre}
Family : Asteraceae.
Common Name $\quad$ : Eng- Dandelion; Hindi- Dulal kanphal.
Parts used : Fruit
Used by Pulaya $\quad$ : The entire plant decoction ios used to cure dyspepsia and digestive problem.
Leaf decoction consumed orally to promote appetite.

\section{Viola odarata $L$}

$\begin{array}{ll}\text { Family } & \text { : Violaceae } \\ \text { Common Name } & \text { : Eng- sweet violet } \\ \text { Parts used } & \text { : Leaves. } \\ \text { Used by Pulaya } & \text { : Leaf infusion taken internally to cure sore throat, cough, tonsillitis and } \\ & \text { asthma. }\end{array}$

\section{Zingiber officinale Roscoe}

Family

Common Name

Parts used

Used by Pulay
: Zingibaraceae

: Eng- ginger ;Tam- Ingi; Hindi- Ada

: Rhizome.

: A bit of fresh rhizome is bitten by the achy tooth to relieve toothache and gastric trouble. Daily twice for three days or until it is cured

\section{REFERENCES}

[1] Warrier, P.K., Nambiar, V.P., Raman Kutty, K., 1994-1996. Indian medicinal plants, a compendium of 500 species. Orient Longman Ltd. Madras. Vol.1-5.

[2] Sathyavathi, R., Janarathanan, K.J., 2011. Folk medicine of Baduga community in Nilgirir International J. of Pharma Research and Development vol 3

[3] Rajandran, R., and Rajan S., 1999. Indigenous knowledge : Its role in the health care practices of Annamalai hills of Coimbatore district, Tamilnadu, India Ancient.Sc.Life 18(3\&4):228-230

[4] Patharaj, J., Kannan, R., 2017. Medicinal plants used by Thoriya ethnic (Sub tribe of Baduga) in Nilgirisz

Citation: Gopi Krishnan R, \& Patharaj J "Some Most Important Medicinal Plants Used by Pulaya Tribes from Thirumoorthy Hills of Tirupur District, Tamilnadu, India" of International Journal of Advanced Research in Botany (IJARB), vol. 5, no. 1, pp. 14-24, 2019. http://dx.doi.org/10.20431/2455-4316.0501003

Copyright: (C) 2019 Authors. This is an open-access article distributed under the terms of the Creative Commons Attribution License, which permits unrestricted use, distribution, and reproduction in any medium, provided the original author and source are credited. 